\title{
Sexual Education of Children With Down Syndrome in Parents Low Education
}

\author{
A.Octamaya Tenri Awaru* \\ Departmen of Sociology Education \\ Faculty of Social Science \\ Universitas Negeri Makassar \\ Makassar, Indonesia \\ a.octamaya@unm.ac.id \\ Supriadi Torro \\ Departemen of Sociology Education \\ Faculty of Social Science \\ Universitas Negeri Makassar \\ Makassar, Indonesia \\ supriadi.torro@unm.ac.id
}

\author{
Andi Dody May Putra Agustang \\ Departmen of Sociology Education \\ Faculty of Social Science \\ Universitas Negeri Makassar \\ Makassar, Indonesia \\ andidody@unm.ac.id \\ Andi Nurmaidah \\ Departemen of Family Welfare \\ Education \\ Faculty of Engineering \\ Universitas Negeri Makassar \\ Makassar, Indonesia \\ a.nur.maida@unm.ac.id
}

\author{
Sofia \\ Departemen of Sociology Education \\ Faculty of Social Science \\ Universitas Negeri Makassar \\ Makassar, Indonesia \\ sofia@gmail.com
}

\begin{abstract}
Sexual education in children with Down syndrome is often ignored by parents, even though the needs and development process children are the Down syndrome same as other normal children. The purpose of this study was to determine the materials and methods used by parents in providing sexual education to children with Down syndrome. This research is a qualitative research, data collection is done by interview and observation. Interviews were conducted with parents who havechildren Down syndrome aged 5-40 years with low education. Data analysis was carried out in three stages, namely data reduction, data display and conclusion drawing. Data verification is done by means of observation, persistence of observation and triangulation of sources and time. The results showed that: 1) sexual education material for people with Down syndrome, namely, a) ages 0-6 years parents introduce body anatomy in the form of gender differences, apply masculinity and femininity to children, educate in caring for the body, decorate and dress, socialize same-sex and intertype procedures for chatting in the family. b) 7-10 years olds are given the habit of covering their intimate parts, educating children's faith, separating children's beds, and educating them to maintain genital hygiene. c) ages 10-14 years away from sexual stimulation. d) ages 14-21 years avoid adultery. 2) The methods applied are a) playing methods, b) peers, c) demonstrations or practices, d) exemplary, e) direct introduction, f) lectures, g) parables.
\end{abstract}

Keywords: Sexual education, Parents, Down syndrome.

\section{INTRODUCTION}

Sexual education has not received special attention from parents or society at large. Parents tend to ignore sexual education because they think that children will know by themselves as their age grows and develops [1]. The same is true for children with Down syndrome. Down syndrome is a disorder that can occur in children since the womb. Children with Down syndrome also lack knowledge about sexuality [2].

Even though their mental development is not like that of children in general, the sexual organs of children suffering from Down syndrome continue to develop normally. This means that sexuality in children with Down syndrome is the same as in children in general who also experience development of sexual organs [3][4].

Accurate data on sexual harassment and violence against children with special needs in Indonesia does not appear to be available, because there are not many cases of sexual violence and abuse reported [5][6]. This proves that the lack of attention to cases of sexual violence experienced by children, even though such cases are very concerning. Some data and cases of child sexual violence that occur, due to children's ignorance of some adult treatment when touching certain body parts in children are wrong. One of the reasons is the lack of information from parents regarding the parts of the body that can be touched and cannot be touched by anyone and which touch is safe and what is not [7][8].

Especially for children with Down syndrome who of course have difficulty in capturing the information provided, parents must pay extra attention to sex education [9][10][11]. It is not an easy thing to educate children with Down syndrome, especially in Lembang with various parental conditions so that they do not send children to special schools available in Pinrang Regency. The education, socialization and sources of information received by parents of children with Down syndrome in rural areas are still lacking, so parents feel uncomfortable when discussing sex with their children. In contrast to urban areas, most parents of children with Down syndrome can easily obtain information about their children's health, special education for their children, especially regarding the application of sexual education to their children.

This is an opportunity for more opportunities for sexual harassment, violence and crimes to occur in children with Down syndrome [12][13]. Information or information about Parents in Lembang District almost never gethow to educate children with special needs such as Down syndrome. Parents who have Down syndrome children in this area have an average low education or only graduated from 
elementary school. Meanwhile, to provide good and correct knowledge of sexual education, adequate knowledge is needed. Yet in this area are found cases of Down syndrome children. What's more related to sexual education, skills and a good and correct way are needed to convey to children withneeds with special Down syndrome.

Delivering information related to sex education to children starting from simple things related to their body organs must be given an explanation of the limitations in the child and must be conveyed repeatedly and using special methods so that children understand well about the function of their body organs, especially vital organs. This is a form of prevention from parents so that children with Down syndrome can avoid sexual deviations [14][15]. Therefore, the purpose of this study is to identify and find and describe the form of sexual education in children with Down syndrome, as well as methods of sexual education for children with Down syndrome.

\section{METHOD}

This research was conducted in Pinrang District, Lembang District, South Sulawesi. This type of research is descriptive qualitative. The technique of determining informants using purposive sampling, to parents who have Down syndrome children aged 5-40 years, and have education low. Based on the saturation of the data, there were 10 informants selected to be research informants. Data collection techniques used are observation, interviews, and documentation. Observation and in-depth interviews were carried out on informants at the informant's house. Data were analyzed using the interactive analysis model from Miles and Huberman [16][17][18].

Research data that has been collected, processed and analyzed using qualitative analysis techniques are as follows; data reduction, namely the process of selecting and concentrating attention and simplifying, abstracting and transforming the rough data contained in the interview notes and the results of observations obtained in the field; presentation (display) of data, namely a set of information that has been arranged which gives the possibility of meaning that can be reported in drawing conclusions; drawing conclusions and verification is carried out after the data is presented, described and given meaning with a logical interpretation. Drawing conclusions is based on data presentation and data reduction. Data verification is done by means of observation, persistence of observation and triangulation of sources and time [19][20][21].

\section{RESULTS AND DISCUSSION}

\section{A. Sexual Education Materials for Children with Down Syndrome}

Sexual education is basically a very important thing to give to children. Gradually, sexual education can be taught according to the child's age to make it easier to capture information related to sexuality that is conveyed by parents. In fact, if parents have a high sensitivity to various issues related to sexuality that often occur, parents will feel more concerned about the education their children get, namely related to sexual education.

For parents with low education and having children with Down syndrome, the sexual education provided is still at astage very simple. In the present study found that sexual education given to children thing very firstis doing an introduction to the anatomy starts from about the gender differences between men and women. If you look at the introduction stage, this is very simple, but parents of children with Down syndrome rarely do it. Of the 10 research informants, only 5 provided knowledge about body anatomy to their children. The introduction of body anatomy is carried out simply by using language that is easily understood by the child so that the message to be conveyed can be managed properly by the child. Especially in children with Down syndrome who are mentally retarded, so it is possible to have difficulty understanding what is being said [22].

The application of simple sexual education material for children with Down syndrome will start the steps with a directed direction, at least parents do early prevention in children with Down syndrome. Parents of children with Down syndrome who apply masculinity and femininity as material related to sexual education are carried out by inserting them into the child's daily activities. For children under 6 years of age who of course spend part of their time playing, parents see this opportunity to instill masculinity and femininity in children. Just giving children games according to their gender is a form of masculinity and femininity.

Furthermore, the third part of the sexual education material for early childhood is caring for the body, making up and dressing. In accordance with the child's age, it is still just introducing the child's identity, giving directions to the child, determining the attitude of the child so as not to take a wrong step later. There are many obstacles faced by parents in conveying how to care for the body in children with Down syndrome because they tend to be abay in caring for themselves.

The results showed that it was related to taking care of the body, to decorate and dress instinctively as a parent who taught this. At the age of under 6 years, parents are still assisted by the parents to take care of their needs, so that in order to provide understanding regarding how to care for the body, make and updress the child is introduced through giving examples. Parents of children with Down syndrome alo apply the same thing, as parents in general who help with all the needs of children.

Furthermore, discussions of same-sex and inter-sex relationships are also part of sexual education material which is important to apply from an early age. Such material is given to children with Down syndrome in order to know more about the limits on themselves and others.

Introducing restrictions on children related to same-sex and inter-sex interactions will be more effective if applied from an early age, even though it is still limited to the world of play, who should play with and who must take care of who is all that needs to be explained and needs to be introduced to children with Down syndrome. Basically, 
when the child withunder 6 years of age, children with Down syndrome have the same catching power as normal children, the only difference being thephysical development slow [23]. But when you are over 7 years old, a significant difference will appear. So whenchildren are Down syndrome still under 6 years old, they need to be given knowledge about social boundaries or friendship boundaries. Even though the form of application of parents of children with Down syndrome is only simple, it is limited to conveying that their playmates are better with the same sex or providing supervision when playing.

Furthermore, related to the relationship in the family or how children chat with the family. It should be noted that even though the child's family relationship is very close to everyone, it is necessary to introduce restrictions in chatting, even in the family. Various cases of sexual violence experienced by the child are actually carried out by the closest person, this is what makes the recognition of boundaries in the relationship between families very important. When people who are in the circle of life actually become a threat to the child, so there must be protection from the child through teaching from parents [24][25].

Parents of children with Down syndrome imposing inrestrictions on children in chatting with the family by introducing courtesy to the child, for example, such as dressing up so that they do not open up even in a family environment, manners when playing with family. Regarding the introduction of adab in children with Down syndrome, whichhope parents will benefit their children later.

The last part is related to sexual education material provided by parents to children with Down syndrome at an early age, namely making various sexual problems something to be aware of so that introspective attitudes can arise in parents and also in children. Seeing various bad events that can happen to children can spur parents to provide more protection for themselves.

Sexual problems are things that need to be prevented from an early age, not only when the child is outside, even in the home environment even though the child needs protection [26][27][28]. Parents of children with Down syndrome who make sexual problems as a basis so that it is necessary to provide sexual education to children to apply it more by instilling fear or a sense of alertness in children, for example by using the term child kidnapper which creates a sense of alertness in children so that they protect themselves more.

In the second stage, the sexual education provided for children aged 7-10 years is more developed than the material for sexual education for ages 0-6 years. At the age of 7-10 years, children are introduced to their own limits as a form of improvement from previous knowledge. If at the age of 0-6 years children are introduced to customs in clothing, then at the age of 7-10 years it is increased by providing personal space for children to get to know more about their boundaries. For example, by introducing intimate body parts that must be taken care of, which parts of the body can be touched or seen, and which parts of the body that cannot be seen and touched by anyone at all.
When entering the 7-10 year age level, children have experienced an increase in capturing the information provided. In contrast tochildren Down syndrome who need extra patience and energy in conveying information to him. Parents ofchildren Down syndrome show that they tend to get their children used to doing things independently, for example in cleaning themselves. Then, parents also accustom children to still have manners in clothing, even if it is related to the issue of parental genitals, it does not reach that part, but parents teach about the parts of their intimate body that must be covered.

Next, related to educating faith in children, it is important because religious knowledge can be a shield for children from various problems that can occur to them. The results obtained related to sexual education material at the age of 7-10 years related to educating children's faith were applied by 5 out of 10 informants who were interviewed. Parents of children with Down syndrome to apply to provide exemplary in children, for example by showing the habits of parents in worship such as prayer, then parents also educate faith to involve children in religious activities in the environment, eg Koran together with kids around. A simple form of modeling like parents in general, which is applied in daily activities in the form of worship which is the obligation of everyone but can stimulate children to follow it.

Next, sexual education material in the form of separating children's beds which is applied at the age of 7-10 years. The results showed that 4 out of 8 informants implemented bed separation in children as a form of habituation forchildren Down syndrome to start independently. Although at first it is the same as children in general who are still with their parents or family when sleeping, but when they enter the age level where they can do it themselves, parents begin to get used to the child.

Sexual education provides detailed instruction to children, even about adab when sleeping is also taught. It is clear that when children are accustomed to mingling while sleeping, there will be a large possibility of deviations, and it is feared that their fellow families will occur. Sexual abuse does not only occur in the outer environment of the child, but it is also likely that it can occur in a narrow scope such as family.

Furthermore, regarding the educational material to maintain sexual (hygienehygiene sex) at the age of 7-10 years, parents of children with Down syndrome educate children to get used to cleaning their intimate organs independently. When they are under 6 years old, everything is still assisted by parents, so when they enter the age of 7 , parents begin to provide space for children to independently be able to maintain the cleanliness of their bodies and their intimate organs. This habit is carried out by parents of children with Down syndrome because of encouragement as parents or guardians for children who of course have to keep the child clean, even though it is not based on the knowledge of sexual education that the parents have. In the process, children often fail to understand, but because they are always getting used to it, their children are able to understand [29][30][31]. 
The importance of educating children to maintain sexual hygiene, so that children have private space for their intimate organs and so that children know more about their limits that they will not always be helped by their parents because there will be a time when they must be independent.

When children enter the age of 10-14 years, which is better known as puberty. So at this age level children will experience many changes in themselves. For example, for girls who have started menstruating, growing breasts, boys have started having wet dreams, or have experienced changes in their voice. Here the role of parents is very necessary to help children through the transition period from children to adolescents.

Based on the results of the research obtained, parents of children with Down syndrome provide sexual education in the form of providing extra protection to them from various sexual stimuli considering that the child has started to experience puberty so that feelings of turmoil can arise when for example meeting the opposite sex. The sexual education material given by parents to children with Down syndrome is in the form of teaching when the menstrual period comes for women, how girls respond to menstruation, how children keep their intimate organs clean. Whereas for boys, parents increase their supervision of the child's association, there is also a discussion about when children have wet dreams, namely how children should react to it. Just to tell children what parents do in general.

When Down syndrome children enter the age level of 14-21 years. In this part, what is important for parents to do is keep children away from adultery. At the age of 14-21 years, the form of sexual education provided by parents to children with Down syndrome is only in the form of increasing protection than in the previous age stage. At this time it is likely that children will begin to express themselves when they have feelings for the opposite sex. Even though parents have low education, they understand very well that their children can become victims of sexual harassment or crimes. Therefore, they are very alert and guard their children to avoid it.

For parents of children with Down syndrome, based on the results of the study, it is known that they apply more about children's boundaries in socializing, when in the previous phase the parents introduced social boundaries, in this phase the child must be able to apply them. Sexual education material given based on age stages as found in this study is relevant to the results of research [32] which found that for parents in the Bugis Makassar family, constructions education there are 4 sexual namely 1 ) sexual education is teaching about genitals; 2) teaching sexual intercourse procedures; 3 ) differentiating the roles of men and women, and; 4) the process of teaching manners to get along with the opposite sex. These four constructs are illustrated in the stages of providing sexual education to children with Down syndrome as in the results of this study.

The basic differences regarding sexual education provided by parents of people with Down syndrome in Lembang District and parents to normal children are simple material given due to ignorance. parents and children's lack of catching power. Access to information related to education sexualis very minimal, making it difficult to teach children. What parents teach children with Down syndrome are only basic sexual education. What they teach is still far from perfect in applying sexual education to their children. However, all social rules are conveyed to their children only so that their children remain in the corridor of values and norms recognized by their village community.

\section{B. Methods of Sexual Education in Children with Down Syndrome}

Based on the results of research conducted on 10 informants who were parents of children with Down syndrome after being classified, it was found that they used at least 7 methods or methods in providing sexual education to their children. The seven methods or ways of providing sexual education to children with Down syndrome are: the play method, the peer method, the demonstration or practicemethod, the exemplary method, the direct introduction method, the lecture method and the parable method.

The playing method applied by parents of children with Down syndrome is considered more effective because children tend to be friends when invited to play together. Usually parents will give directions to children while playing with them. For children with Down syndrome who have impaired brain function tend to find it difficult to provide understanding only through verbal verbally, so that parents combine it with other methods, one of which is the play method.

The peer-to-peer method is one of the methods used by parents with Down syndrome. This method was chosen because it considers that the socialization of children with their play environment is like their peers who must keep going. So that parents often put their hopes on peers or children's playmates to help provide understanding to children with Down syndrome. Parents put their hopes on other parties to help educate their children so that selected peers are because the child's interaction with their friends is more intense.

The demonstration or practice method is one of the most widely applied methods by parents, especially parents who have children with Down syndrome, because children have difficulties with their catching power so parents must have a thousand ways to educate them [33][34]. The demonstration method is applied, for example, when giving examples to girls in putting on sanitary napkins when menstruating, cleaning their underwear, until the mandatory bathing process when they finish menstruation is taught in the form of demonstrations because it is something new for children especially for children with Down syndrome who tend to understand more when given. examples directly to him. Whereas boys are usually taught about personal hygiene, how to practice when we brush their teeth, to clean themselves when a wet dream is finished.

Exemplary methods are applied by parents of children with Down syndrome for matters related to worship that are difficult to explain to them. So, parents provide an example of what is done so that children can imitate. For that parents must be smart in self-control when in front of children, 
because children tend to imitate the attitudes of those around them. From the results ofresearch parental They usually pray in front of their children so that they can see what the process or movement of prayer is like, and so that children know that worship in the form of prayer must be done [35][36].

The direct recognition method is applied by parents of children with Down syndrome by using the child's body parts directly as a medium for parents to convey the information to be conveyed. Usually people from children with Down syndrome convey this when helping children clean their bodies while being given an explanation that there are intimate parts in their bodies that they must protect, they must cover.

The next method is the lecture method as one of the most common methods and is often used by parents when educating their children. The results showed that usually parents of children with Down syndrome combine them with the play method, while accompanying the child to play, they are also given advice and directions for the child. Then combined with other methods. Usually parents give directions in the form of how children should know the boundaries when socializing, regarding maintaining personal hygiene to the intimate parts of their bodies.

After conducting interviews with informants, a new method was found that was also applied by parents of children with Down syndrome, namely the parable method. The parable method is usually delivered for early childhood or children to make it easier for parents to convey information.

Parents of normal children tend to use the lecture or discourse method in providing sexual education due to their normal children's ability to capture, while parents of people with Down syndrome must use the lecture method at a minimum because the child's condition is not possible. If in normal children the use of the parable method in mentioning the term genitalia is not recommended, but for parents of people with Down syndrome it is an alternative method.

Based on the results of the study, it was found that parents of children with Down syndrome did not apply sexual education to the fullest, only teaching children about general things given by parents. Two-way communication is also necessary so that parents can understand their children, and children are also able to understand the information conveyed by parents.

Sexual education given by parents to children with Down syndrome through stages according to age their is very relevant to George Herbert Mead's theory of socialization [37][38]. Based on this theory, the family becomes the first socialization for children and becomes the first teacher for the child. The socialization theory explains the socialization process or stages of human development, which consists of three stages, the play stage, the game stage,stages and other generalized. In accordance with these stages in providing sexual education to children who go through several stages according to their age level and according to their level of understanding. Starting from the imitation process in children who see the behavior of people around them, then starting to understand the real role of the child, to the socialization stage when the child is able to understand his role so that he is able to socialize with the environment, namely family and people around him.

In its implementation, the three stages of child development referred to by Mead are also passed by children with Down syndrome in receiving education from their parents [39][40]. It's just a different age level. For example, in norman children, body anatomy recognition is carried out and can be accepted at the age of 1-5 years, so children with Down syndrome can master it at the age of 7 to 8 years even though their parents delivered since they were 3 years old. The slow pace of children with Down syndrome in responding to stimuli is one of the causes.

\section{CONCLUSION}

Sexual education material for people with Down syndrome, namely, a) ages 0-6 years parents introduce body anatomy in the form of gender differences, apply masculinity and femininity to children, educate in caring for the body, decorate and dress, socialize same-sex and intertype procedures for chatting in the family. b) 7-10 years olds are given the habit of covering their intimate parts, educating children's faith, separating children's beds, and educating them to maintain genital hygiene. c) ages 10-14 years away from sexual stimulation. d) ages 14-21 years avoid adultery.

The methods applied are a) playing methods, b) peers, c) demonstrations or practices, d) exemplary, e) direct introduction, f) lectures, g) parables.

\section{ACKNOWLEDGMENT}

The author would like to thank all the informants who provided assistance and information during the research conducted. The same thing I convey to the Dean of the Faculty of Social Sciences who have provided financial support for this research.

\section{REFERENCES}

[1] A. O. T. Awaru, R. Idris, and A. Agustang, "Sexual Education at High School Sinjai East," in 1st International Conference on Social Sciences (ICSS 2018), 2018.

[2] J. M. LaCombe and R. J. Roper, "Skeletal dynamics of Down syndrome: A developing perspective," Bone, vol. 133, p. 115215, 2020.

[3] G. R. Seltzer, “" Assisted autonomy' and sexual rights for individuals with Down Syndrome," 2020

[4] M. S. Ballan and M. B. Freyer, "Autism spectrum disorder, adolescence, and sexuality education: Suggested interventions for mental health professionals," Sex. Disabil., vol. 35, no. 2, pp. 261-273, 2017.

[5] S. Aziz, "Pendidikan seks anak berkebutuhan khusus," Yogyakarta Gava Media, 2015.

[6] J. L. Hardesty and B. G. Ogolsky, "A socioecological perspective on intimate partner violence research: A decade in review," J. Marriage Fam., vol. 82, no. 1, pp. 454-477, 2020.

[7] K. Sanchez-Eppler and K. Sanchez-Eppler, Touching 
Liberty: Abolition, feminism, and the Politics of the Body. Univ of California Press, 1993.

[8] M. L. Pulido, "Safe touches: creating a school community to prevent child sexual abuse," in Trauma-Informed Schools, Springer, 2019, pp. 1-17.

[9] B. T. McDaniel and J. S. Radesky, "Technoference: longitudinal associations between parent technology use, parenting stress, and child behavior problems," Pediatr. Res., vol. 84, no. 2, pp. 210-218, 2018

[10] K. Lawrence, R. D. Estrada, and J. McCormick, "Teachers' experiences with and perceptions of students with attention deficit/hyperactivity disorder," J. Pediatr. Nurs., vol. 36, pp. 141-148, 2017.

[11] G. Li, G. Hou, D. Yang, H. Jian, and W. Wang, "Relationship between anxiety, depression, sex, obesity, and internet addiction in Chinese adolescents: A shortterm longitudinal study," Addict. Behav., vol. 90, pp. 421427, 2019.

[12] R. Wortley and S. Smallbone, "Applying situational principles to sexual offenses against children," Crime Prev. Stud., vol. 19, p. 7, 2006.

[13] M. Madan and M. K. Nalla, "Sexual harassment in public spaces: Examining gender differences in perceived seriousness and victimization," Int. Crim. justice Rev., vol. 26, no. 2, pp. 80-97, 2016.

[14] R. Hawkins and S. Teng Sze Wei, "Child sexual abuse attributions among undergraduate psychology students in Singapore," J. Child Sex. Abus., vol. 26, no. 7, pp. 839$852,2017$.

[15] A. Jackson, J. Maybee, M. K. Moran, K. WolterWarmerdam, and F. Hickey, "Clinical characteristics of dysphagia in children with Down syndrome," Dysphagia, vol. 31 , no. 5, pp. 663-671, 2016

[16] M. Huberman and M. B. Miles, The qualitative researcher's companion. Sage, 2002.

[17] M. B. Miles, A. M. Huberman, and J. Saldana, Qualitative Data Analysis: A Method Sourcebook. New York: Routledge, 2014.

[18] W. N. Suter, "Qualitative data, analysis, and design," Introd. to Educ. Res. A Crit. Think. approach, vol. 2, pp. 342-386, 2012.

[19] L. J. Moleong, "Metodologi Penelitian Kualitatif, Ed. 33, Bandung: PT," Remaja Rosdakarya, 2014.

[20] A. Agustang, "Pendekatan Penelitian Kualitatif dan Kuantitatif Suatu Tinjauan Kritis," Makassar Andira Publ., 2011.

[21] A. Upe, "Damsid. 2010," Asas-Asas Mult. Res. dari Norman K. Denzin hingga John W. Creswell dan Penerapannya.

[22] R. Gashmard, F. Ahmadi, and S. M. K. Kermanshahi, "Coping strategies adopted by Iranian families of children with Down syndrome: A qualitative study," Medicine (Baltimore)., vol. 99, no. 28, 2020.

[23] T. Lynch, Physical Education and Wellbeing: Global and Holistic Approaches to Child Health. Springer, 2019.

[24] D. Flores and J. Barroso, "21st century parent-child sex communication in the United States: A process review," $J$. Sex Res., vol. 54, no. 4-5, pp. 532-548, 2017.

[25] B. Keeley and C. Little, The State of the Worlds Children 2017: Children in a Digital World. ERIC, 2017.

[26] M. Bauer, S. Hämmerli, and B. Leeners, "Unmet Needs in Sex Education-What Adolescents Aim to Understand About Sexuality of the Other Sex," J. Adolesc. Heal.,
2020.

[27] D. Luhpuri, R. Andayani, and A. Azam, "The Complexity of Sexual Abuse Problems on Children in West Nusa Tenggara: the Culture against the Law," in Third International Conference on Sustainable Innovation 2019-Humanity, Education and Social Sciences (IcoSIHESS 2019), 2019.

[28] K. H. Robinson, E. Smith, and C. Davies, "Responsibilities, tensions and ways forward: parents' perspectives on children's sexuality education," Sex Educ., vol. 17, no. 3, pp. 333-347, 2017.

[29] M. Scardamalia and C. Bereiter, "Child as coinvestigator: Helping children gain insight into their own mental processes," in Learning and motivation in the classroom, Routledge, 2017, pp. 61-82.

[30] A. First, "Are autistic children more vulnerable online? Relating autism to online safety, child wellbeing and parental risk management."

[31] K. Haimovitz and C. S. Dweck, "What predicts children's fixed and growth intelligence mind-sets? Not their parents' views of intelligence but their parents' views of failure," Psychol. Sci., vol. 27, no. 6, pp. 859-869, 2016.

[32] A. O. T. Awaru, "The Social Construction of Parents' Sexual Education in Bugis-Makassar Families," Society, vol. 8, no. 1, pp. 175-190, 2020.

[33] C.-H. Habibe et al., "Comparison of salivary cytokines levels among individuals with Down syndrome, cerebral palsy and normoactive," J. Clin. Exp. Dent., vol. 12, no. 5, p. e446, 2020.

[34] N. L. Rodríguez and M. E. M. Jareda, "Design Process of an Alternate Reality Game (ARG) as a Strategy to Foster Social Support and Well-being of Mothers of Children with ASD," in 2019 IEEE 7th International Conference on Serious Games and Applications for Health (SeGAH), 2019, pp. 1-7.

[35] Z. Mubarrak, F. Saputra, and M. Ridha, "Method of Parents in the Development of Child Prayers Attention Deficit Hyperactivity Disorder (ADHD)(Case Study of ADHD Children in Kulam Kemukiman Syamtarail Village, North Aceh)," Britain Int. Linguist. Arts Educ. J., vol. 1, no. 2, pp. 278-290, 2019.

[36] R. Tumanggor, "Spiritual Neuroscience Learning at Aisyiyah East of Tebet, South Jakarta," Asian J. Contemp. Educ., vol. 3, no. 2, pp. 111-120, 2019.

[37] G. Ritzer and J. Stepnisky, Contemporary sociological theory and its classical roots: The basics. SAGE Publications, 2017.

[38] W. Simon, Sexual conduct: The social sources of human sexuality. Routledge, 2017.

[39] M. Garcia, "Legislating the birds and the bees: Evaluating the effectiveness of state sexuality education mandates," 2020.

[40] A.-A. Deneault, A. Gareau, J.-F. Bureau, P. Gaudreau, and M.-F. Lafontaine, "Fear of failure mediates the relation between parental psychological control and academic outcomes: A latent mediated-moderation model of parents' and children's genders," J. Youth Adolesc., pp. $1-16,2020$. 